\title{
PETROGRAPHIC CORRELATIONS AND MATHEMATICAL ANALYSIS OF LOG SIGNATURES FOR CLAY IDENTIFICATION
}

\author{
By \\ Bijon Sharma
}

April 1992

Work Performed Under Cooperative Agreement No. FC22-83FE60149

\author{
Prepared for \\ U.S. Department of Energy \\ Assistant Secretary for Fossil Energy
}

Chandra M. Nautiyal, Project Manager

Bartlesville Project Office

P. O. Box 1398

Bartlesville, OK 74005

Prepared by

IIT Research Institute

National Institute for Petroleum and Energy Research

P. O. Box 2128

Bartlesville, OK 74005 


\section{TABLE OF CONTENTS}

Abstract.

Introduction

Acknowledgments

Physical and chemical properties of clays and their effect on petrophysical properties

Wireline log responses of different clay and other minerals ....

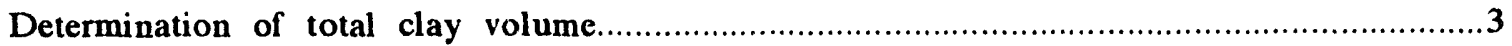

Discrimination of different types of clay and other minerals on crossplots .......................................

Discrimination of predominantly kaolinite type of clays ....................................................

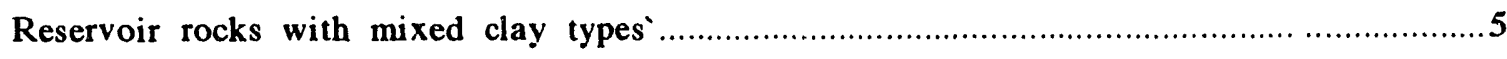

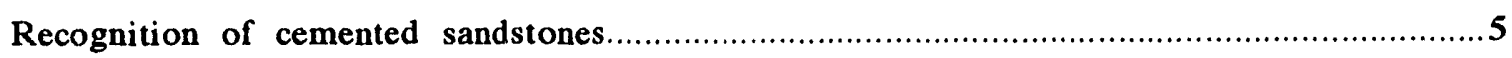

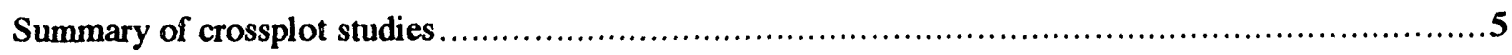

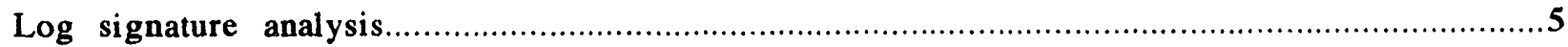

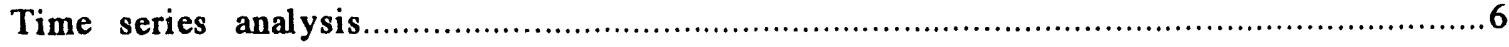

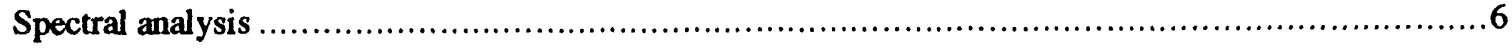

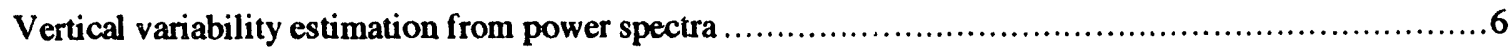

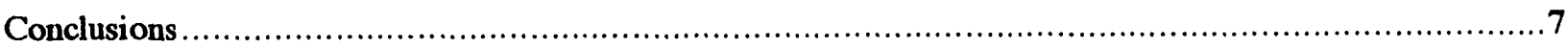

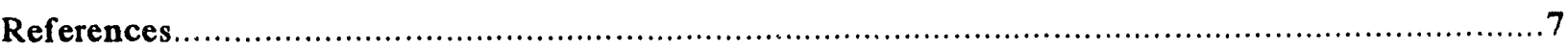

\section{TABLES}

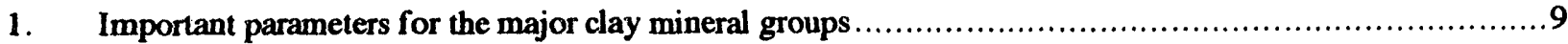

2A. Mineralogical composition and wireline log respones of shaley sandstone in ":sll P-2 in Bell Creek field, MT

2B. Mineralogical composition and wireline log response of shaley sandstone in Arch 120, Patrick Draw field, WY

3. Reservoir and petrophysical properties of UA-5B sandstone of six wells from Arch Unit of Patrick Draw field, WY

\section{ILLUSTRATIONS}

1. Comparison of gamma ray log derived clay content with core measured porosity and air permeability for UA-5B sandstone in well 120, Patrick Draw field, WY

2. Comparison of gamma ray derived clay cvontent with clay and non-clay minerals estimated from XRD analysis for well 120 in Patrick Draw field, WY...

3. Comprison of CT-scan densities and log-derived clay content of well 120, Patrick Draw field, WY ....... 12

4. Crossplot of clay volume $\left(\mathrm{V}_{\mathrm{cl}}\right)$ and bulk density $\left(\rho_{\mathrm{T}}\right)$ of producing UA-5B sandstone in well 120 , Patrick Draw field, WY 


\section{ILLUSTRATIONS (Continued)}

Page

5. Crossplot of clay volume $\left(\mathrm{V}_{\mathrm{cl}}\right)$ and bulk density $\left(\rho_{\mathrm{r}}\right)$ in the barrier island sandstones of well P-2

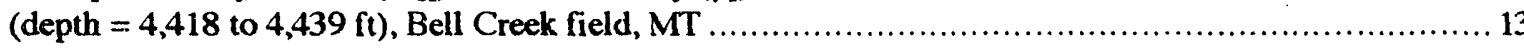

6. Crossplot of clay volume $\left(\mathrm{V}_{\mathrm{cl}}\right)$ and bulk density $\left(\rho_{\mathrm{I}}\right)$ of valley-fill sandstone in well $\mathrm{P}-2$

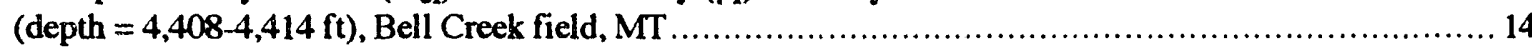

7. Power spectrum of digitized gamma ray log data from UA-5B sandstones in four wells in Patrick Draw field, WY 


\title{
PETROGRAPHIC CORRELATIONS AND MATHEMATICAL ANALYSIS OF LOG SIGNATURES FOR CLAY IDENTIFICATION
}

\author{
By Bijon Sharma
}

\begin{abstract}
This report presents the results of correlation of $\log$ signature with information on distribution of the types and volumes of clays in the sandstone pore spaces determined from detailed CT-scan, XRD, SEM and thin section analyses of core samples from three sandstone reservoirs. The log signatures are then analyzed to determine if suitable mathematical/statistical parameter(s) could be calculated from the logs for identification of types and volumes of clays in sandstone reservoirs.

When a reservoir sandstone has dominantly one type of clay, an easy way to distinguish such a clay is from crossplots of the volume of clay against the bulk density and the neutron porosity of the sandstone. The pattern of distribution of the points in a crossplot is sornctimes a good indicator of the type of clay in a sandstonc. Becausc of differences in cementation and consequent changes in pore throat size distribution, two sandstones having the same amount of identical clay types may have very different production characteristics. These sandstones can be easily identified from a clay volume, density plot. The variation in the vertical distribution of clays within a sandstone seem to have a more drastic effect on permeability of reservoir sandstones than the total volume of clays. Estimates of total clay content by use of gamma ray logs are always on the high side because of the presence of non-clay, radioactive mincrals. The effect of non-clay minerals must be eliminated before good estimates of total clay content in sandstone reservoirs can be madc.
\end{abstract}

From correlations of CT-scan density, gamma ray, sonic, and neutron log data, it was observed that certain thin, shaley beds (less than $1 \mathrm{ft}$ thick) could not always be resolved in the density or the sonic logs when the shale beds have the same density as the matrix rocks, but usually these begis could be identified on the gamma ray and the neutron logs.

A quantitative measurc of the ovcrall variation in clay content and the lithology of sandstone reservoirs could be obtained from the distribution of power contained in the different frequencies (a measurc of rapidity of variation of log data along the depth of well) of gamma ray, density and sonic logs. An effective method for oblaining power distribution is from the time series analysis of wireline log data in clayey formations. For homogeneous, clean sandstones, the distribution of power in the log data as a function of frequency (the so-called 'power spectrum') has high values at low frequencies but sharply decreases at higher frequencies. In heterogenous, clayey sandstones, the power content at the high frequency end remains high, but the power does not drop off sharply with frequency. Depending upon the presence of beds with certain stratification, the power distribution has distinct 'highs' at certain frequencies. The characteristic distribution of power with frequency provides a good measure of the overall clay content and lithologic heterogencity in a sandstone reservoir.

\section{INTRODUCTION}

Depending upon the physical and chemical properties of clays and their mode of dispersal within the pore spaces of reservoir rocks, clays may affect primary, waterflood, and cnhanced oil recovery (EOR) production from hydrocarbon reservoirs in a wide variety of ways. The effect of clays as permeability reducing agents due to their ability to block the movement of fluid through reservoir pore spaces is well known and is the primary cause for the failure of many reservoirs to produce oil. Many times fresh water in drilling mud will cause the clays in a shalc to swell and will result in sloughing and caving of a formation. ${ }^{1}$ The tendency of some clays to migrate through reservoirs as fincs that block pore throats and reduce permeability to fluid is another phenomenon that is sometimes encountered in oil reservoirs. The presence of clays can also create production problems in cerlain well stimulation projects. In a chlorite rich clayey zone, for example, acidizing may precipitatc iron causing significant reduction in permcability. Sometimes excessive production rates may cause the fibrous illite to break loose and start clogging the porc throats which will significantly decrease well productivity. ${ }^{2}$

From the above discussions, it is apparent that for ellicient exploitation of hydrocarbon reservoirs, knowledge about the distribution of the volume and the types of clays and the mode of their dispersal within reservoir pore spaces is of greal importance. Since expensive coring and petrographic studics of rock samples to determine the 
characteristics of clays are not always feasible, this information has to come from analyses of wircline logs after proper calibration of the logs with core data wherever feasible.

Until about a decade ago, the routine methods of obtaining information about the volume of clays from wireline logs were those using the following logs or combination of logs: gamma ray, SP, neutron-density, sonic-density, and sonic-neutron. ${ }^{3}$ All the logging methods depend upon the measurement of certain physical or radioactive properties of clays. Significant progress was made during the past decade in mapping clay volumes and in certain instances the clay types by the introduction of spectral gamma ray logs. ${ }^{4}$ Unlike gamma ray logs which measure the total radioactivity of the formation, the spectral gamma ray measures both the number of gamma rays and the energy level of each that permits the determination of radioactive potassium, thorium, and uranium content in formation rocks. Although specific clay minerals usually have characteristic concentrations of potassium, thorium, and uranium, determination of clay mineral types from spectral gamma ray data is often ambiguous. However, in combination with other data, such as photoelectric absorption coefficient $\mathrm{P}_{\mathrm{e}}$, which is now routinely measured with the litho-density log, the ambiguities in clay identification may be reduced. ${ }^{5}$ The photoelectric absorption coefficient reflects the average atomic number of a formation and is measured by registering the rates at which gamma rays are absorbed as they interact with the electrons in a formation. ${ }^{6}$

In spite of significant strides made in recent years in estimating clay volumes and in identifying clay types with wireline logs, there still remains considerable ambiguities. In situations of mixed lithologies or clay types, the ambiguities are more serious. What is needed is probably a simple method for identification and classification of clay types according to their role as permeability reducing or formation damaging agents. Research is thereforc nceded to extract information about the characteristics of clays from a combined analysis of well logs with production and petrographical data, particularly from some of ihe older fields from where only some of the basic well logs are available. In this research, the available well logs from three fields have been interpreted to determine if signature analysis of the different logs, in conjunction with detailed CT-scan and petrographic studies, can provide information on clays that will allow their identification on wircline logs.

This complex problem of developing suilable techniques for mapping clays has been examined through the following steps:

1. Correlation of log signatures with detailed CT-scan, XRD, SEM, and thin section studies to determine the clay characteristics and the effect of different clays on log signatures.

2. Determination of certain statistical/mathematical properties of $\log$ signatures that may be correlated with clay propertics.

3. Correlation of clay characteristics and mathematical properties developed in (2) above with well productivity.

4. Develop a scheme for mapping clay characteristics that may be useful in understanding hydrocarbon production problems in certain clayey formations.

In this report, which covers tasks 3 and 4, milestone 1 of project SGP42, the results of research conducted so far under itcms (1) to (3) above, are presented.

\section{ACKNOWLEDGMENTS}

This work was sponsored by the U. S. Department of Energy under cooperative agrecment DE-FC22-83FE60149, Project SGP42. The author wishes to thank Dr. M. Madden and Dr. Min Tham for their suggestions and Dr. R. Schatinger and Dr. L. Tomutsa for their assistance in conducting petrographic and CT-scan studies of core samples, respectively.

\section{PHYSICAL/CHEMICAL PROPERTIES OF CLAYS AND THEIR EFFECT ON PETROPHYSICAL PROPERTIES OF SANDSTONES}

The differences in the physical and chemical properties of clays and between clays and the matrix rocks are the basis for mapping distribution of clays in rescrvoir rocks. The dominant clay mincrals commonly encountered in clastic reservoirs exhibit a wide range of physical and chemical propertics (Table 1). Note that the clay properties listed in Table 1 are approximate, average values, and these values may change nver a fairly wide range. For example, sinectite (montmorillonite) can absorb a large volume of water, and in its most hydrated form will have very low density. When subjected to pressure and temperature, it will expel water and will be compressed which will result in a higher measured density. ${ }^{7}$ Additionally, numerous metallic atoms of dilfering weights (aluminum, iron, magnesium, sodium and potassium) can be found in the clay latices. Since the pereentage of these can vary for a given clay type, a wide range of densities is possible.

Two characteristics of clays that strongly affect their cicctrical behavior are the tremendous surface-to-volume ratios of most clays and the charge imbalance along the surface of clay minerals. Two conditions allow for a concentration of ions in the water close to the mineral surface and are quite different away from it. The charge imbalance is due to a greater number of negatively charged 
atoms than positively charged atoms on the clay mineral surface. The brine in the pore system consists of both anions (negative ions) and cations (positive ions). Since opposite charges attract and similar charges repel, the water immediately adjacent to the clay mineral surface is cation enriched and anion deficient. The presence of this cationrich water layer provides a pronounced electrical current path. The amount of charge that may be concentrated by clays is quantifiable and is referred to as cation exchange capacity (CEC). ${ }^{8}$

The property of clays that strongly alfects the petrophysical properties of sandstones is the large specific surface area (surface exposed to fluid per unit volume of solid) of clays compared to any other group of minerals (Table 1). An idea about the strong inverse relationship between specific surface area $\left(S_{o}\right)$ and permeability $(K)$ can be had from the following theoretical equation of Kozeny and Carman : 9

$$
K=\frac{\phi^{3}}{K_{\mathrm{e}} S_{\mathrm{o}}^{2}(1-\phi)^{2}}
$$

where $\phi=$ porosity and $\mathrm{K}_{\mathrm{e}}=$ Kozeny constani.

From the above equation, it may be noted that permeability varies as the first power of porosity and inversely as the square of specific surface area. The strong inverse relationship between specific surface area and permeability and relatively minor effect of specific surface area on porosity is illustrated by a plot of gamma ray log derived total clay volume against the core measured air permeability for the UA-5B sandstone interval in well 120 from Patrick Draw (WY) field, (Fig. 1). The clay in this interval is dominantly kaolinite as indicated by $X R D$ analysis (Table 2B) of core samples conducted by a service company. Note from Table 1 that the dry rock specific surface area of kaolinite is much smaller $\left(20 \mathrm{~m}^{2} / \mathrm{g}\right.$ ) compared to that of the other clays but significantly higher than that in the matrix rocks such as quartz $\left(0.15 \mathrm{~cm}^{2} / \mathrm{g}\right)$. In the presence of clays with higher surface area, the reduction in permeability is expected to be more drastic than that seen in Fig. 1.

\section{WIRELINE LOG RESPONSES OF DIFFERENT CLAY AND OTHER MINERALS}

Table $2 \mathrm{~A}$ shows the mineral percentages of sandstones in well W-7 from Bell Creck (MT) ficld, and in Table 2B, for well 120 from Patrick Draw ficld. The mincral percentages were obtained from XRD analyses of core samples at certain depths. For somc of the depths, SEM photomicrographs were also available that allowed evaluation of the clay types and their mode of dispersal within the sandstone pore spaces.
From carcful log, core correlation the responses of the density, sonic, gamma ray derived $\mathrm{V}_{\mathrm{cl}}$, neutron logs were noted at the exact depths for which XRD analysis are available (Tables $2 \mathrm{~A}$ and $2 \mathrm{~B}$ ). It may be seen from Tables $2 \mathrm{~A}$ and $2 \mathrm{~B}$ and also from Table 1 that gamma ray logs respond very well to the presence of clays although, depending upon the clay type, the effect can be quite variable. From Tables $1,2 \mathrm{~A}$, and $2 \mathrm{~B}$ it may be seen that the density logs may be suitable for distinguishing chlorite type of clays with iron minerals and the illitic clays may be distinguishable from a combination of density and gamma ray logs. High hydrogen content of chlorite and kaolinite may allow recognition of these clays on the neutron logs when used in combination with another type of $\log$ such as the density or the sonic. The very high surface area and CEC values of smectite reduces the resistivity readings in sandstones with these types of clays. When uncompacted, smectite also has much lower density (around $2.45 \mathrm{~g} / \mathrm{cm}^{3}$ ) compared to the density of quartz $\left(2.65 \mathrm{~g} / \mathrm{cm}^{3}\right)$ and therefore could be identified on a total clay content, density plot.

\section{Determination of Total Clay Volume}

An important first step in the cvaluation of any sandstone reservoir is the estimation of total clay content in the reservoir because all flow properties in the reservoir are strongly controlled by the total clay volume percent $\left(V_{c l}\right)$. Although different logging melhods have been used to determine clay volumes, gamma ray logs have been found to be the most effective. ${ }^{10}$ An important source of error in the calculation of clay volumes at Bell Creek and Patrick Draw ficlds was observed to $\mathrm{bc}^{10}$ the $\mu$ resence of fairly signilicant amounts of non-clay, radioactive minerals (like potassium feldspar, mica, ctc.) which emit gamma rays and, therefore, contribute to the total clay volume estimated by the gamma ray $\log$. The result is a net overestimation of the clay volume derived from the gamma ray logs. For example, in Fig. 2 is shown a plol of gamma ray derived $\mathrm{V}_{\mathrm{cl}}$ lor certain depths for well Arch 120 from Patrick Draw ficld for which XRD information is available. The second graph is a plot of the variation in the total percentages of clay minerals from XRD analysis and the third graph is a plot of the total percentages of radioactive mineral content (both clay and non-clay) from XRD analysis at the different depths. The $V_{c l}$ values are sys'cmatically higher than the clay mineral content values, suggesting perhaps that other minerals have also contributed in the the total claty volume cstimates. When the percentages of other non-clay minerals are also added (Fig. 2) there is much belter agrecment with the $V_{\mathrm{cl}}$ graph obtained from the gamma ray log.

Note, however, that there are various sources of error in a direct comparison of total clay mineral percentage with the clay volume derived from gamma ray log. Firstly, not 
all minerals (clay and non-clay) emit cqual amounts of gamma rays so their contribution to total gamma ray count will be 'ariable. While the XRD analyses are cstimations over a very small volume of rock, the gamma ray logs record emissions within a much larger rock volume (around 3 to $4 \mathrm{ft}^{3}$ ). In spite of these possible sources of crror, it would seem from the trend of the graphs (Fig. 2) that the effect of the non-clay minerals must be removed to obtain precise clay volume estimations from the gamma ray log.

\section{DISCRIMINATION OF DIFFERENT TYPES OF CLAY AND OTHER MINERALS ON CROSSPLOTS}

From Tables 1, 2A, and $2 \mathrm{~B}$ and data of physical properties of different minerals, ${ }^{11}$ it may be seen that under appropriate conditions where there is not much mixing of different minerals and lithologies, combined interpretation of two or three logs such as the density and gamma ray logs may be used as a discriminator for identifying certain clay and other mineral types usually encountered in clastic reservoir rocks. To study the effect of density variations at small depth interval (say every 2 in.) on the wireline logs, CT scans using $8-\mathrm{mm}$ - thick X-ray beams were performed on a number of core samples from different fields, such as Patrick Draw, Bell Creek, and Fort Barre (LA). A plot ol CT densities of the producing UA-5B sandstones from well Arch 120 in Patrick Draw field measured every 2 in. as compared with the clay volumes calculated from the gamma ray logs at 6 in. intervals is shown in Fig. 3. The $\mathrm{X}$-ray diffraction analysis of mineral percentages in the core is given in Table 2B. Excellent correlation between $\mathrm{CT}$ density and wireline density has been observed when there is less variation in density within the volume of formation rocks investigated by wireline logs. 12

\section{Discrimination of Predominantly Kaolinite Type of Clays}

Although a mixture of clay types is usually found in sandstone pore spaces, the percentage of onc particular type of clay may be proportionatcly much higher. For predominantly kaolinite type of clays, the bulk density of clayey sandstones will be practically the same as the bulk density of sandstones of low porosity because the density of dry kaolinite clays (around $2.64 \mathrm{~g} / \mathrm{cm}^{3}$ ) is very close to the density of matrix rocks (density of quartz is around 2.65 $\left.\mathrm{g} / \mathrm{cm}^{3}\right)$. This may be noted from Fig. 3 where the bulk density remains practically constant although the clay volume varies appreciably along the depth. The sharp rise in CT density at certain depths in Fig 3, such as at 4,959) $\mathrm{ft}$, was because these were sealed core samples and unlike the other samples, which were dry, had some fluid in the pore space. 12

The crossplot of clay volumes $\left(\mathrm{V}_{\mathrm{cl}}\right)$ and bulk densities $\left(\rho_{r}\right)$ of UA-5B sandstones from well Arch 120 in Patrick
Draw lield, obained from gamma ray and density logs respeclively, is shown in Fig. 4. Most of the points are clustered within a small circle, and from core, log correlations these points within the circle are known to belong to the main sandstone unit. Quite distinct from this random distribution of points within the circular region are two other distribution trends - one trending northeast and the other cast-west. The points in the northeast trend are from the shaley bottom part of the sandstone where the carbonate percentage (mostly dolomite) in the sandstone (indicated by higher density values) is increasing with depth. The east-west trend is again due to increasing percentage of carbonate rocks (mostly calcitc) from the top part of the sandstone where the shale percentage remains practically constant. The points in these two trends are, therefore, not from the main sandstone unit.

From such a plot, therefore, carbonate rocks are distinguishable by their very high density and significantly lower porosity values. Also, calcite beds could be distinguished from dolomites because, unlike the dolomites, which show some radio-activily, pure calcite beds do not emit gamma rays. The $V_{\text {cl }}$ calculated from calcite-cemented sandstones will not vary much if the shale content within the radius of investigation of gamma ray logs docs not change appreciably.

In the main UA-5B sandstone unit, the points in the crosisplot (Fig. 4) are distributed around a central point whose density and clay values are $2.31 \mathrm{~g} / \mathrm{cm}^{3}$ and $6.80 \%$, respectively. This shows that for points within the small circle where clays are predominantly kaolinites, the bulk densities of sandstones change little although there is moderate variation in clay content. This was also evident from the plot of CT scan density against the gamma ray derived claty content for the UA-5B sandstone (Fig. 3).

Similar plots were also made for wells P-2, W-16, and W-7 in Bell Creck lickd, and lor wo "W Wyble No. 1 from Port Barre lield. The producing sanastones in Bell Creck licld consisted of two genetically different sandstones; 13,14 the lower, Barrier lsland sandstone had predominantly kaolinitic clays (Table 2A) with smaller amounts of illites and other clays. The crossplot of clay volume against the bulk density of the barricr island sandstones for well P-2 (Fig. 5) is similar to the plot for UA-5B sandstones in Arch 120 because the clays in both wells are predominantly kaolinites. Points 19-22 (sequentially plotted from the top of the sandstone al every 1 -fi interval) in this plot are from the lower shalcy part of the sandstone and unlike the points from the main sandstone which are bunched together, these generally show an increase in clay content with depth. From the distribution of these shaley points with depth, it appears that an increase of density of these points with depth could be the effect of sediment compaction which is also indicated by the low ncutron porosity (due to low hydrogen content) of these points. The higher clay content 
could be due to an increase in percentage of non-kaolinite clays like illite.

To summarize, it may be noted from the $V_{c l}$, density plot of sandstones in wells Arch 120 and well P-2 discussed above, that when the clays are dominanlly kaolinites, the points from the main sandstonc units are bunched together in the crossplot within a small circle. When the heterogeneity (such as clay volume and typc) in the sandstone increases, the radius of the circle will also increase. Also, depending upon the volume of kaolinite clays, the circle will migrate up and down close to the $\mathrm{V}_{\mathrm{cl}}$ axis, i.e., always within a relatively narrow range of bulk density of the clayey sandstones. The presence of kaolinite clays may be further corrborated from the neutron porosity, density crossplot. Because of high hydrogen index, kaolinite clays will indicate high neutron porosity unless the clays are very compacted, in which case the bulk density of the sandstone will be high (up $102.6 .5 \mathrm{~g} / \mathrm{cm}^{3}$ ).

\section{Reservoir Rocks With Mixed Clay Types}

The clay volume, density plot for the upper, valley-fill sandstones in well P-2 (Fig. 6) show wide scatter of points indicative of highly variable types and volumes of clays in the sandstone. Additional plots completed for wells W-7 and W-16 also indicate similar distribution of points for valley-fill sandbodies which have a mixture of kaolinite, illite and smectite type of clays (sce Table 2A, cstuarinc, valley-fill facies). The points on the crossplot for valleyfill sandstones are distributed along a northeast-southwest trend and cover much wider clay volume and density ranges than the barrier island sandstones. Points 1 and 2 in this plot are in dominantly smectite clays which normally exhibit higher radioactivity than kaolinite clays. The smectites could assume a wide range of density values depending upon compaction. The low-porosity, highdensity compacted smectites for depths 1 and 2 also have relatively low neutron porosity (low hydrogen index).

Well Wyble No. 1 in Port Barre field has penctrated highly clayey, fining upward sequences of diclaic, Wilcoxaged sandstones. The depositional environment of the sandstones has been described as distributary mouth bar. From XRD analysis, the kaolinite clay composition in the sandstone is somewhat smaller compared to illites and chlorites. The measured CT density of the sandstone is much higher compared to those from Bell Creck and Patrick Draw fields. The high-density chloritc clays with iron minerals is distinguishable from other clays from a combination of density and ncutron logs (high hydrogen content of chlorite clays).

\section{Recognition of Cemented Sandstones}

While the clay content in the barricr istand sandstonc in Well P-2 is uniformly low (around 1 10 $2 \%$ ), in well W16 , it is highly variable, and for certain depths it is as high as $16 \%$. For certain depths, there is an appreciable amount of cements (mostly clay and quartz cements) which clog the pore space and drastically reduce permeability. $13-15$ Because of the presence of the relatively higher density cements, the points in the clay volume, density plot for this well are not bunched together but are extended along the density axis. The crossplot for the barrier island sandstones in W-7 also show distribution of points parallel to the density axis within a narrow clay volume range as in the case of well $W-16$, but the densities do not reach very high values. This is believed to be due to a lesser degree of higher density cements in well W-7 compared to that in well W-16.

\section{Summary of Crossplot Studies}

From investigations carried out so far on discrimination of clay types on crossplots of different logs, the following may be concluded:

1. While gamma ray logs provide the best source of data for total clay volume estimation in most cases, the method gives the upper limil of clay content because of the presence of non-clay radioactive minerals. Some knowledye about the percentages of the various radioactive mincrals is required before precise estimations of clay volumes can be made.

2. Sandstones with predominantly kaolinitc type of clays may be discriminated on the $V_{c l}, p_{r}$ crossplot. The radius of the circle of distribution of the points on the crossplot is proportional to the variation in clay content and type in the sandstonc. For predominanlly kaolinite type of clays the points will be cssentially randomly distributed within a sinall circle.

3. The presence of cemented sandstones will extend the points alor.g the density axis but will cover only a narrow range on the clay volume axis.

4. The presence of mixed layer of clays will have the effect of larger scatter of points on the crossplot particularly if the proportion of different clays vary significantly.

5. Chlorite type of clays are distinguishable from a combination of the density and the neutron logs.

\section{LOG SIGNATURE ANALYSIS}

So far discussions on the variation in log responses in claycy formations have been in the depth domain; that is, changes ir log responses along the depth of an oil well have been studied to find the characteristics of a clayey formation. Carclul examination of log responses in sandstone formations indicale that log responses in certain clayey formations have unique signatures. Effective deconvolution of the log sigmatures in different claycy 
formations may provide a method for identification of certain characteristics of clayey formations that arc critical in the exploitation of hydrocarbon reservoirs. A possible method to study the log signatures may be in the frequency domain by making a transformation of the log responses from the depth domain to the frequency (rapidity of variation of responses) domain. The objective of the frequency domain investigation is to determine if certain features of $\log$ signatures in clayey formations would stand out better in the frequency domain than in the depth domain.

\section{Time Series Analysis}

Time series analysis is a powerful mathematical tool that has found wide application in the analysis of engineering, scientific and economic data that arisc in the form of discrete or continuous time series. In the original application, time series analysis was applied only to data which were functions of time, but it has subsequently been applied to a wide variety of physical problems that do not involve time. In this work, the mathematical technique of time series analysis will be applied to digitized log clata which are available as a function of depth.

The time series is a random or nondetcrministic function whose future behavior cannot be predicted cxaclly, as in the case of a deterministic function. The different portions of a time series resemble each other only in certain average behavior. This obscrvation has led to the notion of stochastic processes in which the behavior of time series is predicted by probability laws or models.

\section{Spe :tral Analysis}

An important aspect of time series analysis is spectral analysis which is concerned with the splitting up of the time series into different frequency components. Once the series is split into its components a whole range of operations can be performed on the individual frequencies to derive information on the characteristic features of the time series.

Suppose, for the moment, that the time series $x(t)$ consist of the value of the cosine function given by

$$
x(t)=a \cos \left(2 \pi f_{O} t+\phi\right)
$$

where $f_{0}$ is the frequency of the cosine function, a is the amplitude of the cosine function, and $\phi$ is the phasc.

If $\mathrm{N}$ is the total number of points in the time suries, the fundamental frequency of the scries is given $b_{y} 1 / N$ and all frequencies $f_{0}$, into which the time series has becn split up, will be multiples of the fundamental frequency. It has been demonstrated ${ }^{16-17}$ that for a series such as the cosine serics described above, the variance or the average ac power of the series is given by a $2 / 2$. For a mixture of cosine waves, its variance can be decomposed into components of average power a $2 / 2$ at the various frecuencies. Statisticians have shown 16,17 that if $x(1)$ is a stationary time series, the variance of the stochastic process can be decomposed into contributions at a continuous range of frequencies according to

$$
\sigma^{2}=\int_{-\infty}^{\infty} \tau(f) d f
$$

where $\sigma^{2}$ is the variance of the time series. $\tau(f)$ is called the power spectrum of the stochastic process. Thus $\tau(f) \delta f$ is an approximate measure of the average power or variance in the frequency band $f$ to $f+\delta f$.

A computer program developed for calculating the power spectrum from the digitized log data was previously discussed ${ }^{18}$ In brief, an autocovariance function is first estimated from the log data digitized at 0.5-ft depth intervals. Since power spectrum and autocovariance functions are fourier transform pairs, fouricr transformation of the autocovariance function will give the power spectrum. The formula for the smoothed sample spectrum cstimatc $C_{x x}(f)$ in the digital form is icduced to the following equation: 16

$$
C_{x x}(f)=2 \Delta\left\{c_{x x}(0)+2 \sum_{k=1}^{L-1} c_{x x}(k) w(k) \cos 2 \pi f k \Delta\right\}
$$

where $\Delta=$ sample interval, $c_{x x}(0)=$ autovariance function all $\mathrm{l}=0$,

$c_{x x}(k)=$ autocovariance lunction for different lags $k$, and

$w(k)=$ the lags window with truncation point $M$.

To obtain a better smoothed estimate of the spectrum, the entire time series is divided into $\mathrm{k}$ series each of length $M=N / k$. The mean of the spectral estimates of $k$ series gives a better spectral estimate than that given by a single time serics.

Computer programs have been developed for calculating both the power spectrum as well as the spectral density which is obtained by normalizing the power spectrum by dividing it by the variance of the time scries, $\sigma^{2}$.

\section{Vertical Variability Estimation from Power Spectra}

in the above discussions on power spectrum computations, it was stated that the power spectrum gives the variance at cach frequency. The original time series 
(digitized log data) may be split into a number of frequencies and variances calculated for each frequency. The technique for estimation of vertical variability of rock propertics in a well is illustrated from power spectra of gamma ray logs of UA-5B sandstones in Patrick Draw field. The rock and petrophysical propertics of sandstones in six wells and their cumulative primary production data are given in Table 3 . The porosity and the air permcability data in the table are from laboratory measurements of core samples, and the clay content values are derived from interpretations of gamma ray logs. An approximatc, single value estimate of the vertical variation of clay distribution in the six wells was obtained from the standard deviation of clay distributions for individual sandstoncs (Table 3).

The power spectra for sandstones from four wells calculated from digitized gamma ray logs are shown in Fig. 7. The spectrum for a clcan sandstone or a sandstone with very uniform clay distribution should show rapid attenuation of power with frequency. This is illustrated by the smooth attenuation of spectra for well 79. Well 120 is only 1,600 ft. west of well 96 and the two sandstones are very similar except that the sandstone in well 120 is slightly shalier than that in well 96 . The spectrum for well 120 shows small humps at discrete frequencies indicative of the shaley zones in this will which werc absent in well 96. The relative cleanness of the two sandstones is given by the smoothness and the gradient of spectral decay for the two wells at different frequencies. The sandstorie in well 71 is the most heterogenous with large vertical variations in clay distributions. The power spectrum for this sandstone (Fig. 7) shows high power for the entire frequency range due to gamma ray cmissions from beds of all thicknesses. From power specrum calculatons for a large number of sandstones it was shown earlier $^{19}$ that low power at the high frequency end and smooth attenuation of this power is probably an important criteria for the sandstone to have high effective permeabilities. This may be explained by the fact that relatively high power at the high frequency end implics presence of a large number of very thin beds which could impede fluid movement in the reservoir and reduce elfective permeability of the sandstonc.

Similar decay curves generated for other logs provided o.jantitative estimates of other reservois properties. For example, the spectral decay curves for density logs in wells 96 and 120 have very low powers throughout the entire frequency range with power for well 120 slightly higher than that for well 96 because it is slightly shalier. The low power in the density spectra is because the density logs show very slight variation for the entire sandstone thickness because the clay content in these sandstones are not highly variable and the matrix rocks as well as the kaolinite clays in the sandstones have very nearly the sanne density, i.e., $2.65 \mathrm{~g} / \mathrm{cm}^{3}$. The density spectrum for the valleyfill sandstone in well $\mathrm{W}-7$ in Bell Creek ficld indicates much higher spectral values because the sandstonc porcspaces are filled with a mixture of clays having different densitics.

\section{CONCLUSIONS}

The following conclusions may be drawn from rescarch conducted so lar on development of techniques for mapping the volume and the type of clays:

1. In cases studied thus far, gamma ray logs provide the best source of information for estimating the clay volume. For precise estimation of clay volume, however, the volume of raciioaclive non-clay mincrals is required which can be oblained only from petrographic studies or spectral gamma ray logs. Without the correction for non-clay, radioactive mincrals, the calculated clay volume from the gamma ray logs will give the upper limit of clay content in the sandstone.

2. The crossplot of density and clay volume can distinguish sandstones having kaolinite clays, highly cemented sandstones and also the degree of heterogeneity present in the sandstone pore spaces due to different types of clay and cements cte. The chlorite clays are also distinguishable on such a crossplot becausc of high densitics of chlorites.

3. Combining clay volume, density crossplot with crossplots for clay volume and neutron porosity and clay velume and sonic transit time, the presence of smectitc type of clays may be distinguished under favorable circumstances. No dala, however, have been analyzed for significant thicknesses of sandstones with dominantly smectite type of clay. Some information about the degrec of compaction of the clays can be derived from the densities of sequential points on the crossplot.

4. An objective estimate of the vertical variability of rock propertics (like the clay content) can be made from the decay curves of power spectra calculated from digitized well logs. Paramelers of the power spectra at various frequencies, such as smoothness, slope and the value it attains at the extreme high frequency end may be correlated with the degrec of shaliness and approximate permeability of the sandstone.

\section{REFERENCES}

1. Vithal, A.. A. (jupla, and M. M. Sharma. A Rule Based System for Estimating Clay Distribution, Morphology, and Formalion Damage in Reservoir Rocks. Pres. at the 62nd Annual Tech. Con \& Exhibit, Dallas, 'IX, Sepl. 27-30, 1987. SPl: Paper 16870.

2. Iiertl, W. Il., and (3. V. Chilingartan, Type and Distribution Mode of Ciay Mincrals from Well logging Data. Journal of Petroleum Science \& Engineering, Vol. 3, No. 4, 1990, pp 321-332. 
3. Dewan, J. T. Essentials of Modern Open-hole Log Interpretation. PennWell Books, Tulsa, OK 983, pp. 227-265.

4. Gamma Ray Spectral Logging. A New Evaluation Frontier. Reprinted from World Oil. Gulf Publishing C.o., Houston, 'TX, 1983.

5. Gardner, J. S. and J. L. Dumanoir. Lilho-Density Log Interpretation. SPWLA Logging Symposium Transactions, Junc 1976.

6. Schlumberger Educational Services. Log Interpretation Principles/Applications. Houston, TX, 1987.

7. Asquith, George B. Log Evaluation of Shaley Sandstones: A Practical Guide. AAPC; Continuing Education Scries \#31, Tulsa, OK, 1989.

8. Almon, W. R. A Geological Apprecialion of Shaley Sands. SPWLA Symposium 1979, paper WW.

9. Dullen, F. A. L. Porous Media.Fluid Transporl and Pore Sirusture. Academic Press., New York, New York, 1979..

10. Poupon, A. and R. Gaymard. The Evaluation Clay Content from Logs. SPWLA Symposium, 1970, paper G.

11. Crain, E. R. The Log Analywis Ilandbook. PennWell Books Tulsa, OK, 1986

12. National Institute for Pctrolcum and Encrgy Rescarch. Quarterly Technical Report for April.june 1991. Volume II, Energy Production Research. DOE Report NIPIER-545, July 1991, pp. 33 34.

13. Sharma, B., M. M. Llonarpour, M. J. Szpakicwič, and R. Schatzinger. Critical Heterogencitics in a Barricr Island Deposit and Their Influence on Primary, Waterlood and Chemical I:OR Operations. SPE formation Evaluation, March 19\%().

14. Sharma, B., M. M. Honarpour, S. . Jackson, R. Schatzinger, and L. Tomutsa. Determining the Productivity of a Barrier Island Sandstone Deposit From Integrated Facies Analysis Bascd on Log and Corc Data and Fluid Production. SPE Formation Evaluation, December 1990.

15. Szpakicwicz, M., K. McGec, and 13. Sharna. Geological Problems Retated to Characterization of Clastic Reservoirs for I:OR. SPIE Formation Evaluation. Dec., 1987, pp. 449-60.

16. Jenkins, (j. M. and Donald (3. Watts. Spectral Analysis and Its Applications. Holden-Day, San Francisco, 1968, pp. 141-257.

17. Bendat, S., and $\Lambda$. (j. Piersol,. Random Data: Analysis and Measurement Procedure. Wiley-Interscience, $\wedge$ Division of John Wilcy and Sons, Inc., New York, 1971, pp. 286.341.

18. National Institute for Petroleum and lincrgy Rescarch. Quarlerly Technical Report for July.Seplember 1990, Vol. II, Einergy Production Research. DOI: Repon NIPI:R-5()1, October, 19)(0, pp. $92-100$.

19. National Instutute for Petroleum and Energy Research Qinarterly Technical repori for January - March, 1991. vol II, linergy Production Rescarch. DOI: Report NIPI:R-52\%, May, 1991, PP. 76-79. 


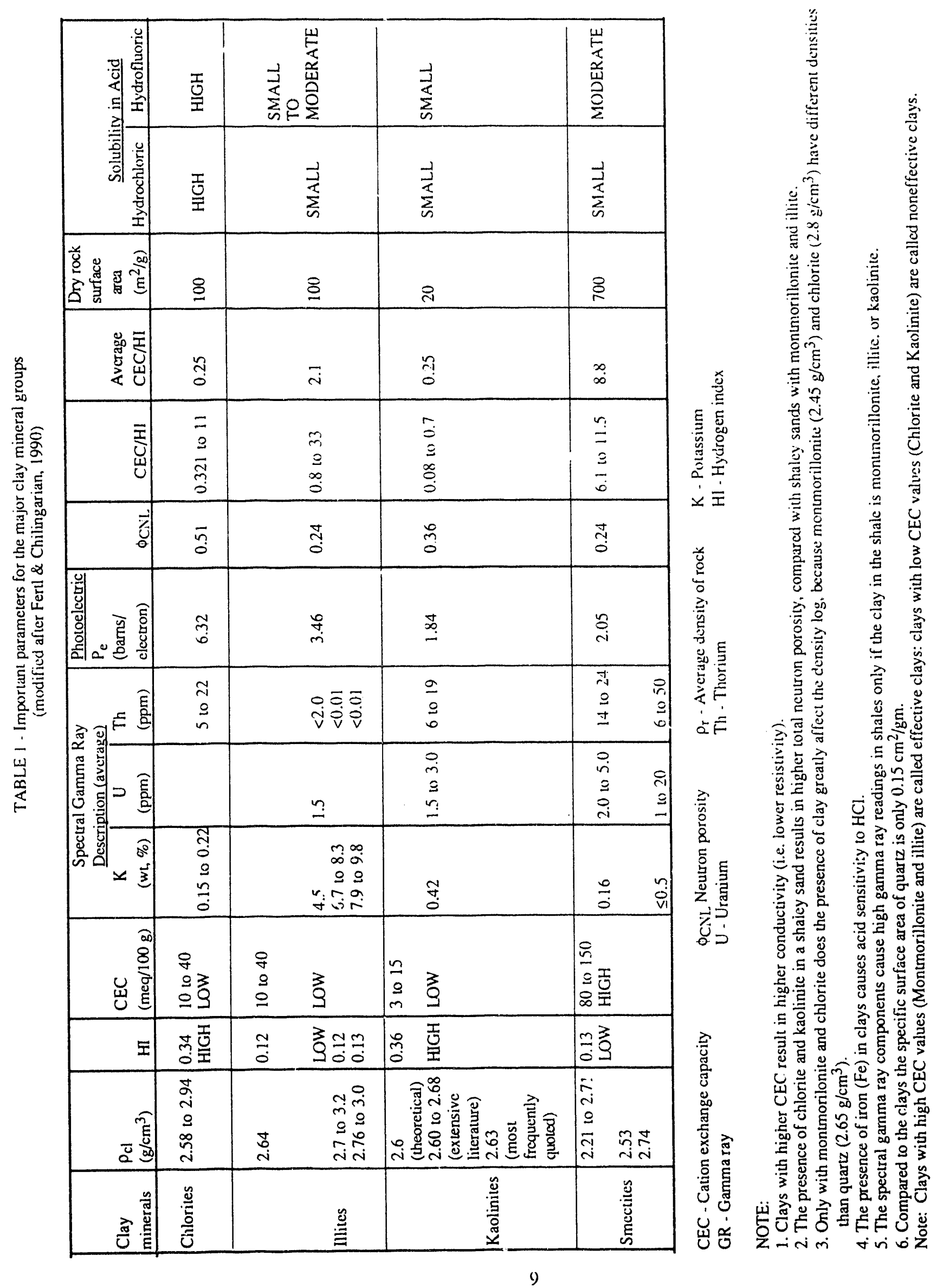


TABLE 2A. Mineralogical composition and wireline log responses of shaley sandstone in well W-7 in Bell Creek field, MT. Mineralogical percentages obtained from XRD analysis of core samples.

\begin{tabular}{|c|c|c|c|c|c|c|}
\hline Sample number & 1 & 2 & 3 & 4 & 5 & 6 \\
\hline Depth, ft & 4405.5 & 4410.0 & 4417.5 & 4418.9 & 4419.5 & 4431.3 \\
\hline Depositional setting & Estuarine & Estuarine & Swamp & Alluvial channel & \multicolumn{2}{|c|}{ Top of U. shoreface } \\
\hline Quartz, wt \% & 88 & 79 & 92 & 96 & 94 & 91 \\
\hline Feldspar, wt \% & 4 & 4 & 3 & 1 & 2 & 3 \\
\hline Calcite, wt \% & - & . & . & - & - & - \\
\hline Dolomite, wt \% & trc & - & - & - & - & - \\
\hline Barite & - & - & - & - & - & 2 \\
\hline Kaolinite & 2 & 2 & 3 & 3 & 2 & 2 \\
\hline Illite & tre & trc & tre & tre & 2 & 2 \\
\hline Smectite & 6 & 15 & 2 & tre & trc & trc \\
\hline \multicolumn{7}{|l|}{ Log responses } \\
\hline $\mathrm{V}_{\mathrm{cl}}, \%$ & 35.3 & 33.7 & 8.9 & 29.6 & 33.6 & 1.5 \\
\hline $\begin{array}{l}\text { Density, } \mathbf{g} / \mathrm{cm}^{3} \\
\text { Neutron porosity, \% } \\
\text { S, micro-sec }\end{array}$ & $\begin{array}{l}2.418 \\
45 \\
92.5\end{array}$ & $\begin{array}{l}2.434 \\
43.5 \\
92\end{array}$ & $\begin{array}{l}2.226 \\
45 \\
85\end{array}$ & $\begin{array}{l}2.354 \\
44 \\
86.5\end{array}$ & $\begin{array}{l}2.338 \\
45 \\
91.5\end{array}$ & $\begin{array}{l}2.153 \\
50.5 \\
103.5\end{array}$ \\
\hline
\end{tabular}

TABLE 2B - Mineralogical composition and wireline log response of shaley sandstone in Arch 120, Patrick Draw field, WY. Mineraiogical percentages obtained from XRD analysis

Sample number

Depth, $\mathrm{ft}$

Quartz, wt \%

Feldspar, wt \%

Calcite, wt \%

Dolomite, wt \%

Siderite, w: \%

Pyrite, wt \%

Kaolinite, wt \%

Illite and/or Mica, wt \%

Mixed-layer

Illite/Smectite, wt \%

Plagioclase Feldspar, wt \%

Feldspar K, wt \%

Log responses

$\mathrm{V}_{\mathrm{cl}}$ from G.R., wt \% $\quad 10.5$

Density, $\mathrm{g} / \mathrm{cm}^{3}$

Neutron porosity, \%

$\mathrm{S}$, micro-sec
2

4942.4

52

3

36

1

42

23

11

1 trc

$\begin{array}{ll}1 & 3 \\ 2 & 3\end{array}$

2.497

18.9

68

4944
66
6
3
19

2
3
1
trc
3
3

6.09

2.436

20.6

65

3

(1)

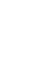

3

4948.7

82

6

4

1

3

3

1

trc - Traces of minerals
S - Sonic transit time

$\mathrm{V}_{\mathrm{cl}}$ - Clay volume from gamma ray log 
TABLE 3. - Reservoir and petrophysical properties of UA-5B sandstones of six wells from Arch Unit of Patrick Draw field, WY

\begin{tabular}{|c|c|c|c|c|c|c|}
\hline Well no. & $\begin{array}{l}\text { Average clay } \\
\text { content, } \%\end{array}$ & $\begin{array}{c}\text { Variation } \\
\text { in clay } \\
\text { distribution } \sigma, \%\end{array}$ & $\begin{array}{c}\text { Average } \\
\text { porosity, } \\
\%\end{array}$ & $\begin{array}{l}\text { Average (geom.) } \\
\text { permeability, } \\
\text { mD }\end{array}$ & $\begin{array}{l}\text { Cum prod, bbl/ } \\
\text { year drilled }\end{array}$ & Comments \\
\hline 71 & 5.6 & 2.26 & 20.4 & 8.1 & $\begin{array}{l}\text { no production/ } \\
1964\end{array}$ & $\begin{array}{l}\text { UA-6 } \\
\text { production }\end{array}$ \\
\hline 79 & 5.6 & 0.95 & 20.7 & 78.0 & $\begin{array}{l}2.88 \times 10^{5 /} \\
1964\end{array}$ & $\begin{array}{l}\text { UA-5 } \\
\text { production }\end{array}$ \\
\hline 91 & 7.7 & 1.45 & NA & NA & $\begin{array}{l}2.12 \times 10^{5} / \\
1966\end{array}$ & $\begin{array}{l}\text { UA-S } \\
\text { production }\end{array}$ \\
\hline 96 & 5.0 & 1.23 & 20.8 & 16.3 & $\begin{array}{l}1.55 \times 10^{5 /} \\
1967\end{array}$ & $\begin{array}{l}\text { UA-5 } \\
\text { production }\end{array}$ \\
\hline 100 & 4.5 & 1.04 & 20.4 & 13.00 & $\begin{array}{l}0.75 \times 10^{5} / \\
1967\end{array}$ & $\begin{array}{l}\text { UA-5 } \\
\text { production }\end{array}$ \\
\hline 120 & 6.9 & 1.09 & 17.5 & 14.7 & $\begin{array}{l}\text { no production/ } \\
1987\end{array}$ & $\begin{array}{l}\text { UA-5 } \\
\text { production }\end{array}$ \\
\hline
\end{tabular}

o - Standard deviation of clay distribution NA - Data not available 


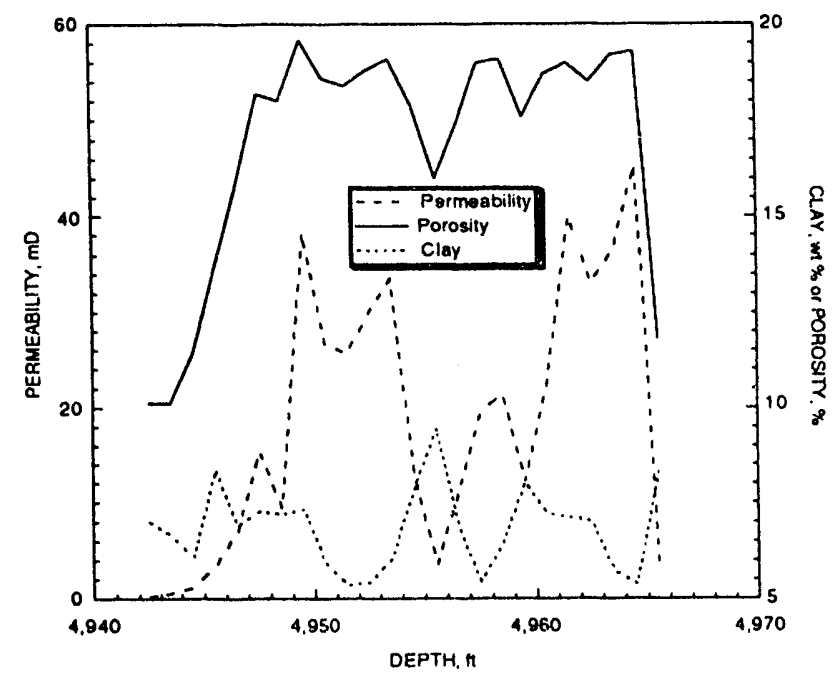

Figure 1. - Comparison of gamma ray log derived clay content with corc measured porosity and air permcability for UA-5B sandstone in well 120, Patrick Draw ficld, WY.

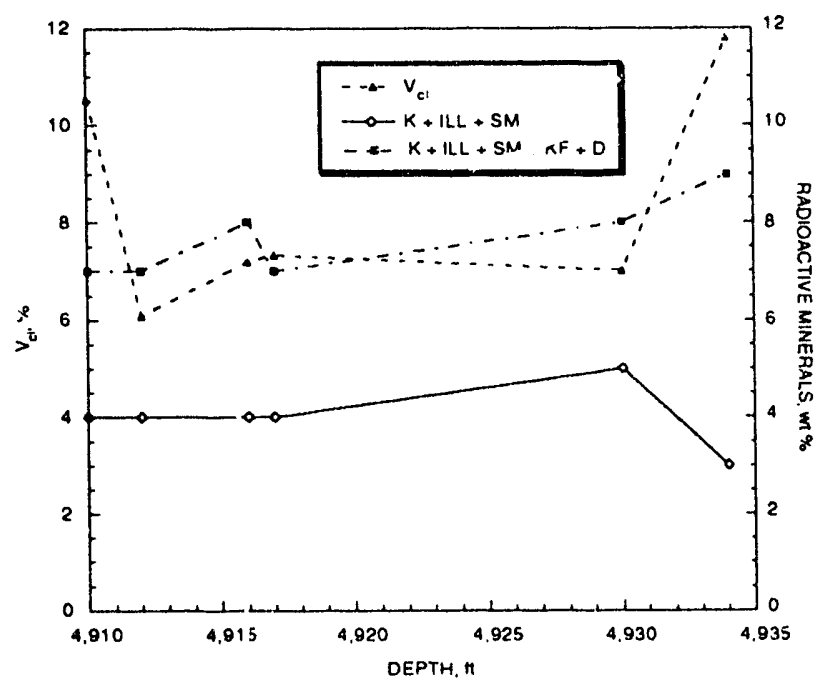

Figure 2. - Comparison of gamma ray derived clay content with clay and non-clay mincrals estimated from XRD analysis for wcll 120 in Patrick Draw ficld, WY, $\mathrm{V}_{\mathrm{cl}}=$ claly content $\mathrm{K}=$ kaolinile. ILL $=$ illite, $S M=$ smectite. $K F=$ potussium feldspar, $D=$ dolomitc.

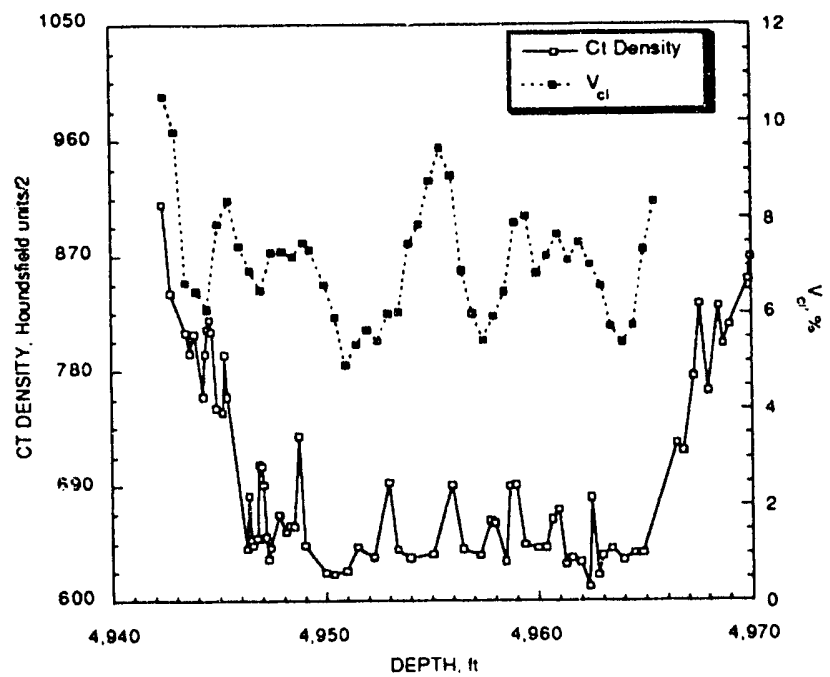

Figure 3. - Comparison of CT-scan densities and logderived clay content for wcll 120, Patrick Draw licld, WY.

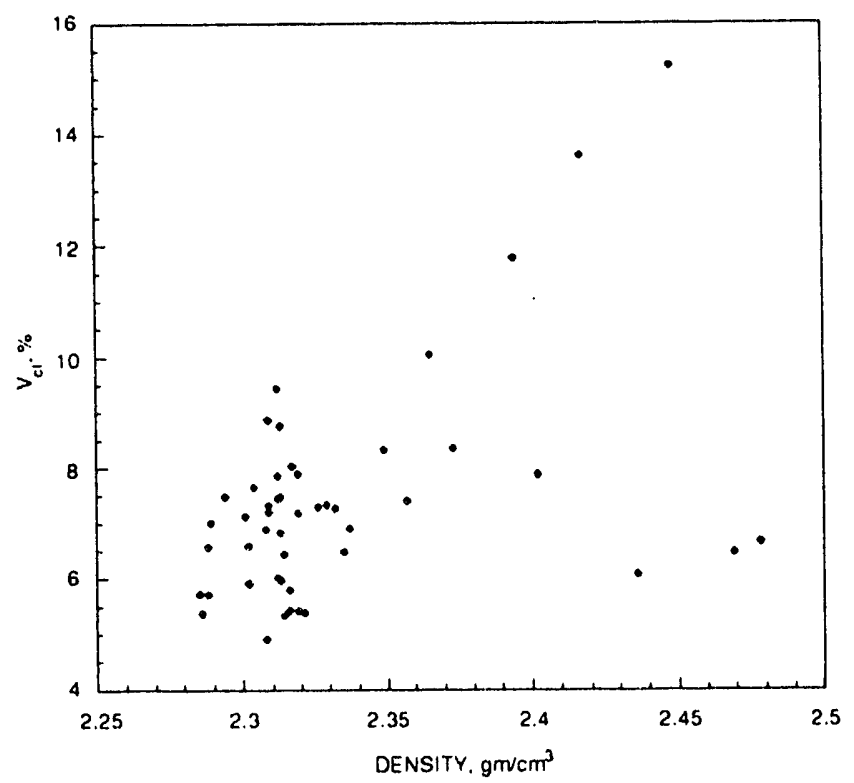

Figure 4. - Crossplot of clay volume $\left(V_{\mathrm{cl}}\right)$ versus bulk density $\left(\rho_{\mathrm{r}}\right)$ of producing UA-5B sandstone in well 120, Patrick Draw ficld, WY. 


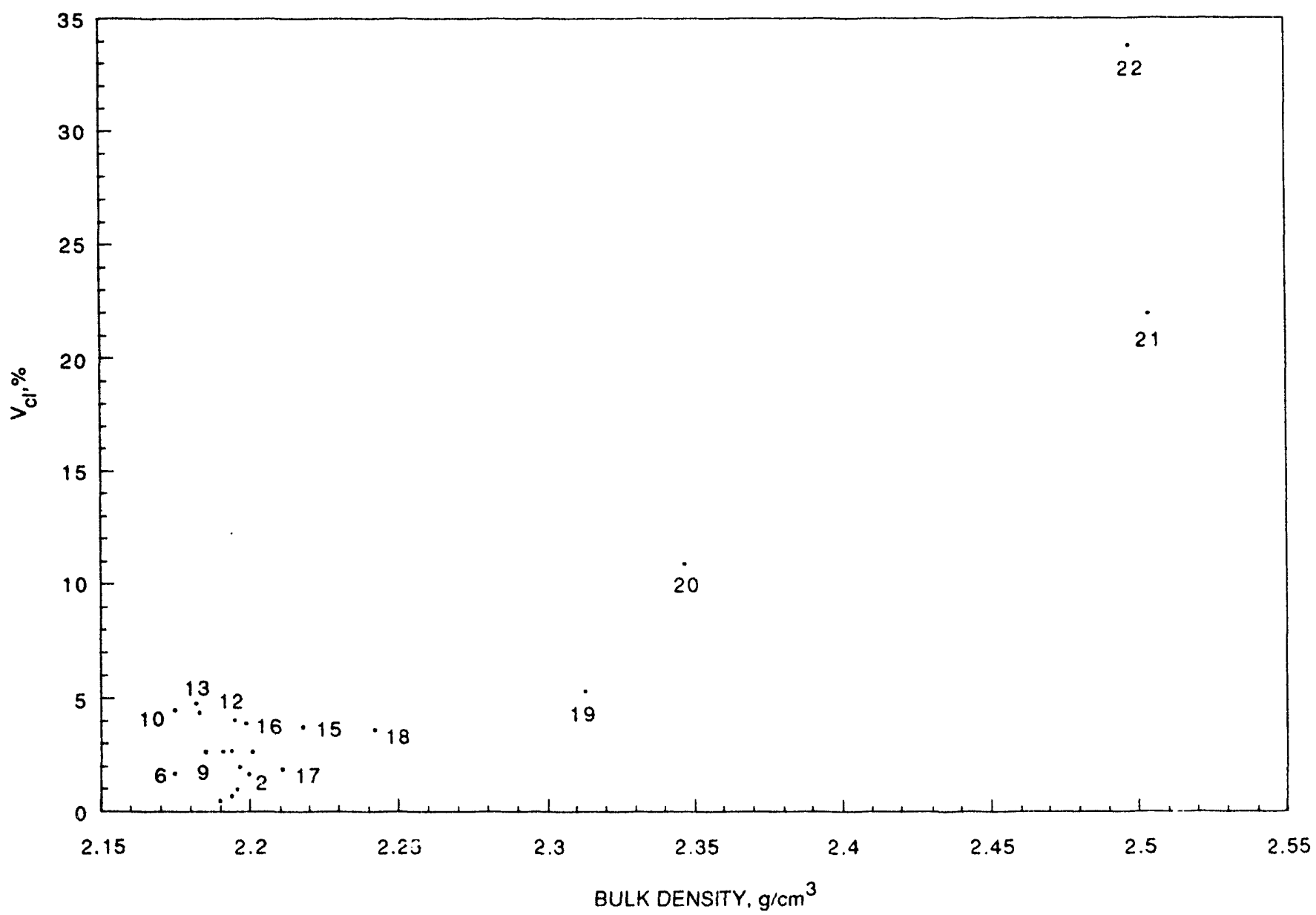

Figure 5. - Crossplot of clay volume $\left(\mathrm{V}_{\mathrm{cl}}\right)$ versus bulk density $\left(\mathrm{P}_{\mathrm{r}}\right)$ in the barricr island sandstones of well P-2 (depth $=$ 4,418 to 4,439 fi), Bell Creck ficld, MT. 


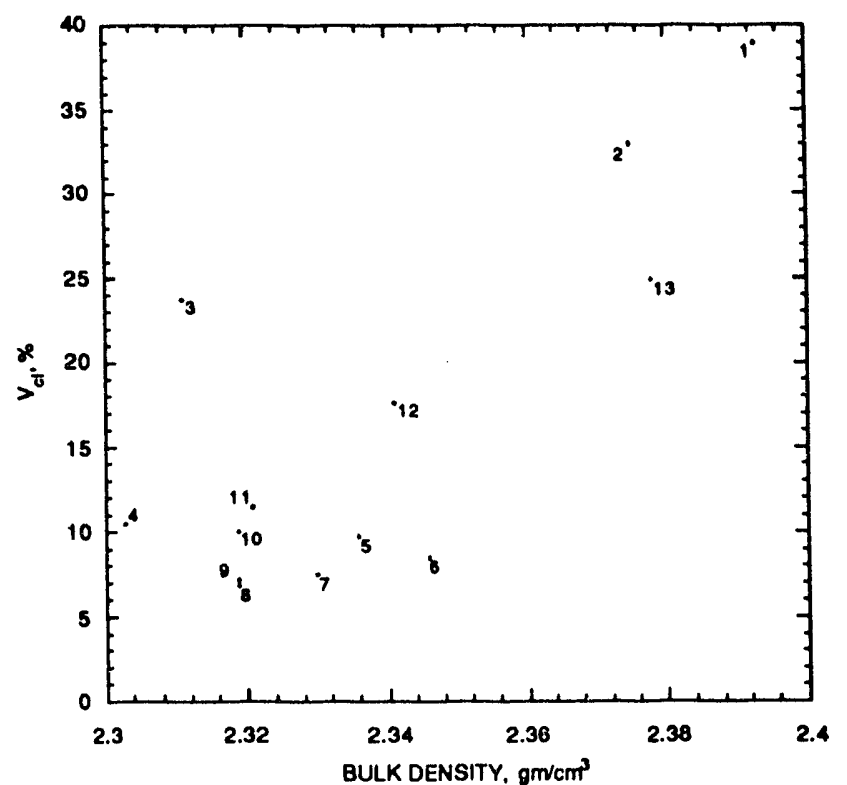

Figure 6. - Crossplot of clay volume $\left(\mathrm{V}_{\mathrm{cl}}\right)$ and bulk density $\left(\rho_{\mathrm{r}}\right)$ of valley-fill sandstone in well P-2 (depth $=4,408-4,414 \mathrm{ft}$ ), Bell Creek field, MT.

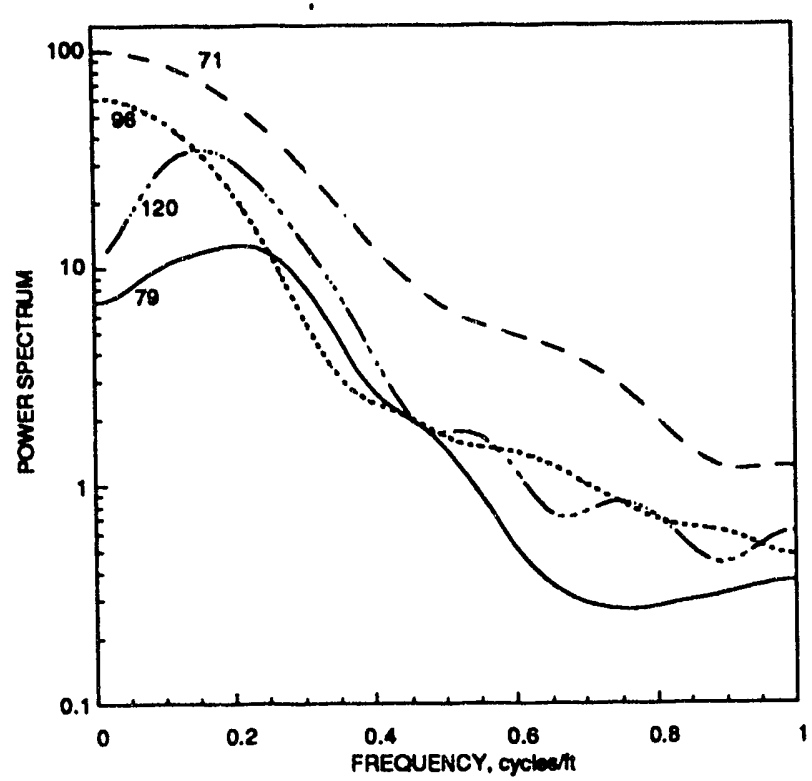

Figure 7. - Power spectrum of digitized gamma ray log data from UA-5B sandstones in four wells in Patrick Draw field, WY. 


\section{$\$$}
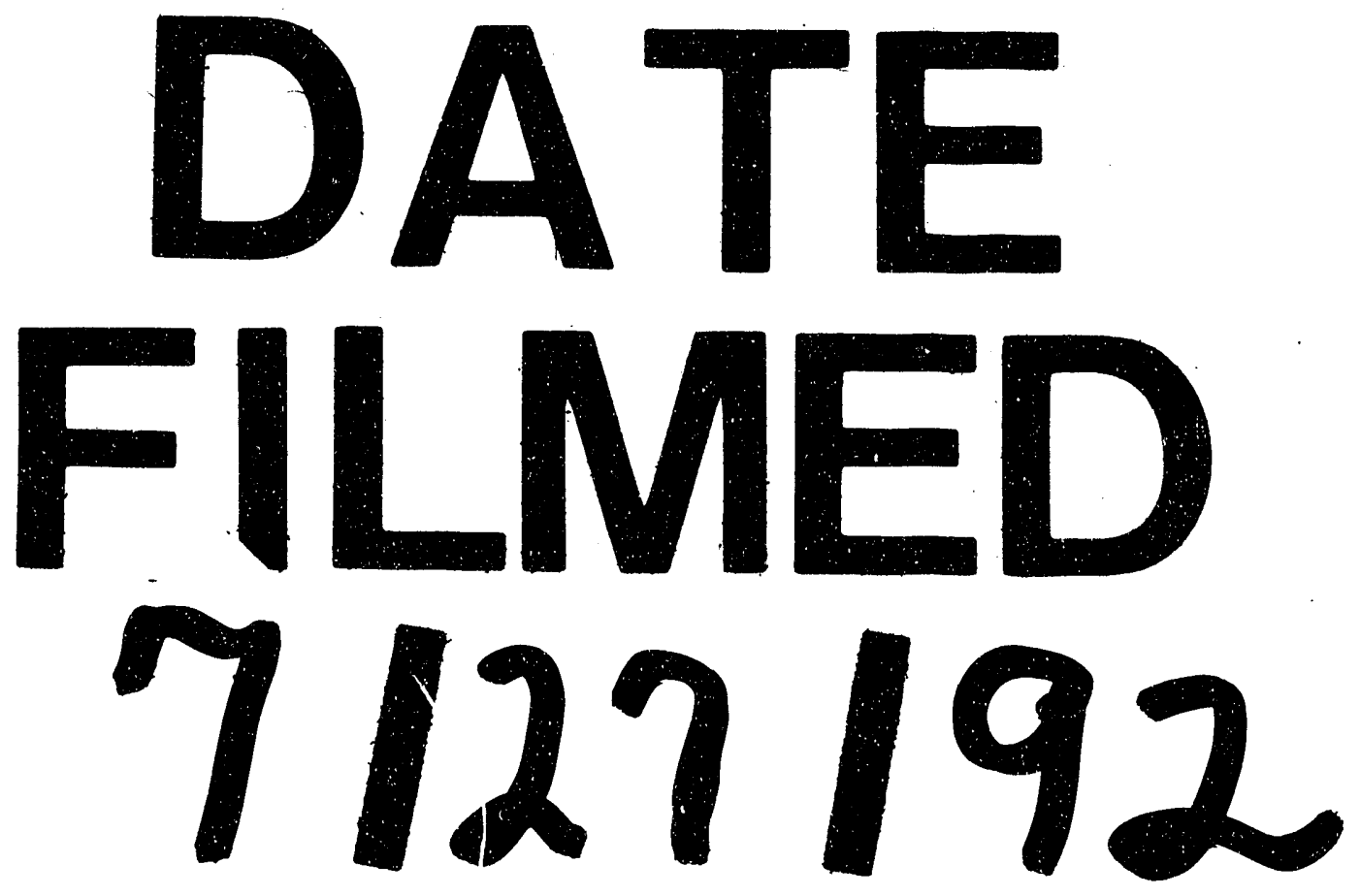
